\title{
RUSYA POLIS YAPILANMASINDA MODERNLEŞME VE KAMUOYU
} ALGISI"

\author{
Muhittin TATAROĞLU** \\ $\ddot{O}_{z}$
}

Rusya coğrafi genişliği, uluslararası siyaset alanında önemli bir aktör olması, kendine özgü siyasi, idari, sosyal ve kültürrel yapıslyla önemli ülkelerden biridir. Sovyetler Birliği dağllınca, yerine kurulan Rusya ve ayrlan diğer devletler siyasi, ekonomik, idari ve toplumsal tüm yapıların dönüşürrme sürecine girmişlerdir. Bu süreçte kültürel ve ulusal değerler farklı bir yapllanma sürecine girmiştir.

Rusya kolluk yapısının 2000'li yillarda gösterdiği değişim ve reform süreci ilk elde suç sayısında azalma, kolluk teşkilatı hakkanda kamuoyunda olumlu algıların artması gibi sonuçlar vermişstir. Bu gelişme toplumların ancak güvenlik, asayiş ve huzur sağlandıktan sonra, ekonomik, siyasi, sosyal ve diğer hümanist boyutlartyla gelişebileceği gerçeği bakamından önemlidir.

Çalışmada farklı araştırma yöntemleri kullanılmıştır. Rusya kolluk teşkilatının tarihçi-kurumsal yaklaşımla tasvir edilmesinde yazll birincil kaynaklar ve mülakatlardan yararlanılmıştır. Rusya kolluk teşkilatının geçirdiği yapısal ve işlevsel dönüşüm ise ilgili, yasalar, kararlar, talimatlar ve diğer mevzuatin incelenmesi, kurumlarin incelenmesi, sahada yapllan birinci elden gözlemler ve mülakatlarla değerlendirilmiştir. Yararlanılan istatistiksel verilerin güvenilirliği ise karşılaşttrma yöntemleriyle sorgulanmışttr.

Anahtar Kelimeler: Kolluk Hizmetleri, Polis, Reform, Rusya.

\section{MODERNIZATION AND PERCEPTION OF PUBLIC IN RUSSIAN POLICE STRUCTURE}

\begin{abstract}
Russia is one of the important countries with its geographical width, being an important actor in the field of international politics and its unique political, administrative, social and cultural structure. After the collapse of the Soviet Union; Russia and other countries gaining their independence went through the process of transforming all their political, economic, administrative and social structures. Within this process, cultural and national values entered into a different transformation.

The change and reform process of the Russian law enforcement in the 2000s, yielded positive results such as a decrease in the number of crimes in the first hand and an increase in the public perceptions about law enforcement. This development is important in terms of the fact that societies can only develop in economic, political, social and other humanist dimensions after security, public order and peace are ensured.

Various research methods were employed in the study. In describing the Russian law enforcement organization with a historical-institutional approach, written primary sources and interviews were used. On the other hand, the structural and functional transformation of the Russian law enforcement agencies has been evaluated through various ways including the examination of relevant laws, decisions, instructions other legislation, examination of institutions, first-hand observations and interviews in the field. The reliability of the statistical data was questioned by comparison methods.
\end{abstract}

Keywords: Law Enforcement, Police, Reform, Russia.

"Çalışmada yazarın "Rusya'nın İç Güvenlik Yönetimi” adlı eserinden geniş ölçüde yararlanılmıştır (Tataroğlu, 2019). Çalışma 19-20 Eylül 2019 tarihinde Uluslararası Güvenlik Kongresi'nde sunulan “2000’li Yıllarda Rusya Polis Yapısındaki Gelişmeler” konulu bildirinin geliştirilmiş halidir.

** Doç. Dr., MSKÜ, Kamu Yönetimi Bölümü, muhittintataroglu@yahoo.com, https://orcid.org/0000-00019071-6720 


\section{GíRiş}

Güvenlik bir topluluğun en temel gereksinimidir. Güvenlik, toplumu oluşturan bireylerin birbirleriyle ilişkilerini düzenler ve bu ilişkilerde haksızlık ve adaletsizlikleri önler; toplumun bir arada yaşamasını sağlayan normların uygulanmasını sağlar. Güvenlik olmadığı takdirde toplumun bir arada yaşaması mümkün değildir; toplumsal düzen işlemez hale gelir ve toplum varlığını sürdüremez, nihayetinde dağılır.

Sovyet Birliği'nin son yıllarında kamu yönetiminin tüm boyutlarıyla işlevlerini yerine getirememesi, özellikle kolluk teşkilatının hemen tümüyle yozlaşarak toplumun güvenlik gereksinimi karşılayamaması, sistemin çökmesi ve ülkenin dağılmasının başlıca sebepleri arasındadır. Sovyetler Birliği dağıldıktan ve Rusya Federasyonu kurulduktan sonra girişilen reform çabaları 1990'lar boyunca fazla başarılı sonuçlar ortaya koyamamıştır. Art arda yapılan reform çabaları ancak 2010'lu yıllardan itibaren somut başarılara ulaşmaya sergilemeye başlamıştır.

$\mathrm{Bu}$ dönemde suç istatistikleri düşmeye başlamıştır. Polis teşkilatının halkla ilişkiler boyutunda gerçekleştirilen düzenlemelerin de katkısıyla kamuoyunda kolluk teşkilatı algısında da olumlu gelişmeler gözlenmiştir. Sovyet döneminde vatandaşın en gündelik yaşam detaylarına müdahale eden ve korku salan militsia döneminin ardından 1990'lı yıllarda güvenliği sağlamak ve suçtan korumaktan ziyade suç örgütlerinin nüfuzuna girmiş; suç mağduru vatandaşların tekrar mağdur olma korkusuyla polise müracaat etmekten çekindiği bir kolluk geçmişinden sonra elde edilen bu başarılar oldukça anlamlıdır.

\section{1- RUSYA’NIN İDARİ VE SIYYASİ YAPISI}

Rusya Federasyonu (Rossiyskaya Federatsiya) Sovyetler Birliğinin dağılmasından sonra 24 Ağustos 1991 tarihinde kurulmuştur. Yönetim şekli federal cumhuriyettir. 7 milyon kilometrekare yüzölçümü ile dünyanın en geniş devletidir. Nüfusu 2017 y1lı itibariyle 146.800.000 kişidir. Nüfusun yaklaşık dörtte üçü şehirlerde; dörtte biri ise kırsalda yaşamaktadır. Nüfus sayısı ve şehir-kırsal dağılımı uzun yıllar önemli değişim göstermemektedir (GKS, 2018). Ülkede 160'dan fazla etnik grup yaşamaktadır. Resmi dili Rusça ve başkenti Moskova'dır (Erdem, 2017:186) .

SSCB'de uygulanmaya çalışlan komünizmi, Marksist söylemli bir resmi ideoloji, siyasal sistemin Komünist Parti tarafindan baskı altına alındığı, ekonominin merkezi planlamayla yürütüldüğü ve özel mülkiyetin bulunmadığı, fikir ve ifade özgürlüğünün kısıtlandığı, basının devlet tekelinde olduğu, kuvvetler 
ayrılığının ve yarg1 bağımsızlığının sınırlandığı bir sistem olarak özetlemek mümkündür. Aynı şekilde Devlet ve Parti, vatandaşların en gündelik yaşam detaylarına kadar müdahale etmiştir.

SSCB'de yaşamın tüm boyutlarına Komünist Parti hakim olmuş; devlet organlarının faaliyet ve kararlarına fiilen yön vermiştir. SSCB kağıt üzerinde her biri bağımsız, ayrı bir devlet başkanı, hükümet, yarg1 ve yasama organlarına sahip 15 Cumhuriyetten oluşmaktaydı. Ancak fiiliyatta bağımsız ve egemen değillerdi. Cumhuriyetlerin hepsinde asıl güç yerel Komünist Parti teşkilatında toplanmış, Parti'de ise Rus unsurunun egemen olduğu katı bir merkeziyetçilik hüküm sürmüştür. Cumhuriyetlerde idare ve güç, fiiliyatta Moskova'daki Parti merkezinden emir alan yerel Komünist Parti'nin ve yine merkezin direktiflerine göre hareket eden ve etkin mevkilerinde genellikle Rusların bulunduğu $\mathrm{KGB}^{1}$, polis teşkilatı ve diğer güvenlik makamlarının elinde olmuştur (Baharçiçek ve Ağır: 2016: 13)

\section{RUSYA FEDERASYONU İÇ GÜVENLİK YAPISI}

2010 yılında çıkan "Güvenlik Yasası", eski Sovyet tarzı militsia anlayışının terk edilmesi ve liberal demokrasi tercihine uygun düzenlemeler getirmektedir. “Güvenlik Yasası”nın 2.maddesine göre Rusya güvenlik sisteminin unsurları yasama, yürütme ve yargı makamları, tüm idari kurumlar, dernekler, yasalara göre güvenliğin sağlanmasında yer alan kişiler ve güvenlik alanında ilişkileri düzenleyen mevzuat tarafından oluşmaktadır (Zakon, 2010).

\subsection{Devlet Başkanı}

Rusya'da baş güvenlik sorumlusu Devlet Başkanıdır. Başkan, Güvenlik Konseyine başkanlık eder, toplumun güvenliği için kararlar alır ve talimatlar verir ve güvenlik yetkililerinin faaliyetlerini denetler, koordine eder. Rusya Güvenlik Konseyi, Devlet Başkanının güvenliğe yönelik kararların hazırlanmasından sorumludur.

\subsubsection{Ulusal Muhafizlar (RosGvard)}

Ulusal Muhafizlar Devlet Başkanına bağlı jandarma işlevini yerine getiren, geniş ölçekli isyanlarda ve iç silahlı çatışmalarda polis teşkilatını destekleyen kolluk birimidir. Aynı zamanda önemli yapıların (nükleer santraller vb) korumasını da sağlar. Kamu düzeninin korunmasına ve kamu güvenliğinin sağlanmasına katk1

\footnotetext{
${ }^{1}$ KGB, (Komitet Gosudartsvennoy Bezopasnosti) Devlet Güvenlik Komitesidir. Günümüzde yerini FSB'ye -Federal Güvenlik Hizmetleri- (Federalnaya Slujba Bezopastnosti) bırakmıştır.
} 
sağlamak, önemli kamusal tesislerin, ulaşım ve haberleşme tesislerinin korunmas1, terör ve aşırılıkla mücadele, olağanüstü hal ve terörle mücadelede, kamusal düzeni sağlamaya katkıda bulunmak, devlet sınırlarının korunmasında FSB'ye destek sağlamak diğer görevleri arasındadır (Rosgvard, 2018).

\subsubsection{Federal Koruma Servisi- FSO (Federalnaya Slujba Ohrahi Rosskii)}

Federal Koruma Servisi, Devlet Başkanı da dahil olmakla birlikte üst düzey devlet görevlilerini ve bazı kamu binalarını korumakla görevli ve hükümete bağlı bir kolluk teşkilatıdır. Teşkilat, 1990 yılına kadar faaliyet gösteren Sovyet Dönemi KGB'sinin 9. Dairesinin yerine kurulmuştur (FSO, 2018).

\subsubsection{Devlet Başkanı Güvenlik Servisi}

Devlet Başkanının kişisel korunmasına hizmet eden bu örgütlenme devlet hiyerarşisi içinde resmi bir birim değil, FSO'nun (Federal Koruma Servisi) bünyesinde yer alan ve kişisel yakın koruma sağlayan personelden oluşan bir birimdir. Bu birim de FSO gibi KGB'nin 9. Dairesinden devralınmıştır. Birim, Başkan'ın yakın korunması hizmetini sağlar. Ayrıca Birim içinde yer alan Psikolojik Güvenlik Departmanı da Başkanın hayatına yönelik güvenlik tehditler ile ilgili toplanan bilgilerin analizini yapar (Agentura, 2018).

\subsection{Savunma Bakanlığı}

Savunma Bakanlığı, ülke savunması işlevini icra eden Rus Silahlı Kuvvetleri ve diğer birimlerden oluşur. Bakanlığın yönetimi, Savunma Bakanının başkanlık ettiği bakan yardımcıları, Bakanlığın üst düzey ana bölümlerin yöneticileri ve askeri birliklerin komutanlarından oluşan bir kurul şeklinde yönetilir.

Esas faaliyet alanı ülke savunması olmakla birlikte bünyesinde Askeri Polis (Voennoi Politsii) teşkilatını barındırmaktadır. Askeri alanda kolluk hizmetleri askeri polis tarafindan yerine getirilmektedir.

Askeri polisin görevleri şunlardır:

-Silahlı Kuvvetlerde hukuk, düzen ve askeri disiplinin güçlendirilmesini sağlamak,

-Silahlı Kuvvetlerde trafik güvenliğini sağlamak, bu alandaki özel kontrol, denetim ve ruhsatlandırma işlerini yapmak,

-Asker ve yol güvenliğini sağlamak. Askeri birimlerin hareketlerini, araçların yollarda güvenli seyrini ve bakımını sağlamak ve koordine etmek. 
-Acil durum, askeri saldırı veya doğrudan saldırı tehdidi durumlarında ve savaş zamanlarında askeri birimlerin ulaşım ve intikallerini koordine etmek (MILL, 2018).

\subsection{Sivil Savunma, Acil Durumlar ve Doğal Felaketlerle Mücadele Bakanlığı (EMERKOM)}

Acil Durumlar Bakanlığı, sivil savunmanın düzenlenmesi ve doğal afet ve yangından korunma görevlerini yerine getirmektedir. Bakanlık 1994 yılında kurulmuştur. Sovyetler Birliği'nde daha önceleri de acil durumlar ve afetler için farklı örgütlenmeler olsa da günümüz anlamında ilk merkezi yapılanma 1988 yılı Ermenistan Depremi ve 1990 yllındaki Çernobil nükleer santral felaketlerinden sonra gerçekleşmiştir. 1990 yılında Yüksek Konsey Başkanlığı, "Rusya Kurtarma Birlikleri”ni (Rossiiskii Korpus Spasatelei) kurmuştur. 1991 yılında ise İçişleri Bakanlığı bünyesinde Sivil Savunma, Olağanüstü Durumlar ve Doğal Afetlerle Mücadele Komitesi kurulmuştur. 1994 yılında Komite bakanlığa dönüştürülmüştür. 2002 y1lında Rus Devlet İtfaiye Teşkilatı 278.000 itfaiyeci personeliyle birlikte İçişleri Bakanlığı bünyesine devredilmiştir (MCHS, 2018).

\subsection{Federal Gümrük İdaresi (FTS. Federalnaya Tamojennaya Slujba)}

Rusya Gümrük İdaresi 1865 yılında Maliye Bakanlığına bağlı Gümrük Departmanı olarak kurulmuştur. 1917'de Sovyet Gümrük İdaresi, Ticaret ve Sanayi Halk Komiserliği'nin (MKTP) bir parçası olarak faaliyet göstermiştir. 1991 yılında Sovyet Gümrükleri Ekonomik Gelişme Bakanlığı altında, Devlet Gümrükleri Komitesine dönüşmüş; 2006 yılında ise bugünkü yapısına kavuşmuştur (Customs, 2018).

\subsection{Federal Güvenlik İdaresi FSB (Federalnaya Slujba Bezopasnosti)}

FSB, Rusya'da asli güvenlik teşkilatıdır ve 1991 -1995 yılları arasında kısa bir dönem var olan "Federal Karşı İstihbarat Teşkilatı"nın FSB adı altında örgütlenmesiyle, Sovyet dönemi KGB'nin yerini almıştır. Sovyet Dönemindeki öncülleri 1917 yılında kurulan ÇEKA, 1922 y1lında kurulan GPU (1923'de OGPU), 1934 yılında NKVD (İçişleri Halk Komiserliği) bünyesine alınması, 1946 yılında İçişlerinden ayrılan Devlet Güvenlik Bakanlığı (MGB) teşkilatının, 1953 yılında tekrar İçişleri Bakanlığıyla birleşmesinden sonra 1954 yılında kurulan KGB, Sovyetler dağılıncaya kadar sürdü. (FSB, 2018). Bu derece sık değişikliğe uğramasının altında yatan neden, siyasi elitlerin güç mücadelesi ve bu teşkilatın ise dönemin en önemli iktidar denetim aracı olmasından kaynaklanmaktadır. 
FSB, Devlet Başkanlığına bağlıdır. Denetimi ve FSB Başkanının atanması ve görevden alınmasında Devlet Başkanı yetkilidir. FSB'nin kuruluş yasasında, faaliyet ve yetkilerin kullanımında hukuk devleti, hümanist değerler ve temel hak ve özgürlüklere uyulması gibi konulara tekraren vurgular yapılmış ve Anayasa ve yasalarca belirtilen durumlar dişında "kişi” veya "vatandaş"ın hak ve özgürlüklerinin kısıtlanamayacağı hükme bağlanmıştır. Kurum tarafindan hak ve özgürlükleri kısıtlandığını düşünen kişiler FSB, Savcılık ve mahkemelere başvurabilirler; maddi ve manevi zararlarının tazminini isteyebilirler (Zakon, 1995). Üstelik FSB personelinin davranışları ve işlemlerinden zarar görenlerin maddi ve manevi zararlarının karşılanmasını Yasa, FSB veya Mahkemelere "yükümlülük" olarak yüklemiştir (Md.6). Yasada bu ifadelerin yer almasını, sadece şekli olarak değerlendirmek çok isabeti bir değerlendirme olmaz. Daha çok Sovyet dönemi kolluk teşkilatının negatif anlayışından kurtulma isteği şeklinde yorumlamak daha gerçekçi olacaktır. Özellikle son yıllarda FSB tarafından haksızlığa uğradığı şikayetiyle FSB üst makamları ve yargı organlarına başvuran kişilerin lehine sonuçlanan pek çok idari ve yargı kararına rastlanmaktadır.

FSB'nin temel görevleri iç güvenliği sağlamak, istihbarat, karşı istihbarat, organize suçlar, terör ve uyuşturucu kaçakçılığı ile mücadele, sınır güvenliği ve bilgi güvenliğinin sağlanmasından oluşmaktadır.

Yabancı İstihbarat Servisi Ülke dışında istihbarat faaliyetlerini yürütür. Daha önce KGB bünyesinde yer alan birim, Sovyetler dağılınca iç istihbarat faaliyetleri FSB'ye bırakılarak, dış istihbarat faaliyetleriyle yetkilendirilerek Devlet Başkanına bağlı olarak örgütlenmiştir.

FSB'nin Sınır Hizmetleri Birimi PSFSB (Pograniçnaya Slujba Federalnoi Slujbi Bezopasnosti) Sınır Birlikleri ya da Sınır Muhafızları olarak da adlandırılan Sınır Hizmetleri, FSB' bünyesinde bir alt birim olarak düzenlenmiştir. Sınır birlikleri, sahil koruma birlikleri de dahil olmak üzere 170.000 aktif personelden oluşmaktadır.

Sınır Muhafızları, devlet sınırlarının korunması, sınırlardan insan, mal, araç, hayvan kargo geçişini kontrol etmek, sınırlarda gerçekleşen ticari, ekonomik ve diğer faaliyetleri denetlemek ve kural ihlallerini önlemekle görevlidir. Sinır Muhafızları, sınır ihlallerini, yasadışı insan, mal, hayvan araç vs. geçişlerini önlemek ve bastırmak için operasyonel arama, istihbarat, bilgi toplama ve diğer tedbirleri alır. Sınır ihlallerinin aktifleştiği dönemlerde diğer birimlerle birlikte özel 
sınır operasyonlarını hazırlar ve yürütür. Komşu ülkelerin sınır birimleriyle ortak operasyonlar yürütür (PS, 2018). Ancak "devlet sınırı" kavramı karasal sınırlar, deniz, bölgesel deniz, su altı, münhasır ekonomik bölgeler ve kıta sahanlıklarını da kapsadığı için, birimin faaliyet alanı oldukça geniş ve karmaşıktır.

\subsection{Adalet Bakanlığı-MíNYUST (Ministerstvo Yustitsii)}

Rusya Adalet Bakanlığı ilk olarak 1802 yılında kuruldu. Dönemin adalet bakanı aynı zamanda Rusya İmparatorluğunun Başsavcısı unvanına da sahipti. İlk dönemlerinde adalet bakanlıkları mahkemelerin ve savcılığın faaliyetlerinin yönetilmesinin yanı sıra, yasa yapma görevine de sahip olmuştur. Sovyetler Birliği kurulduğunda bakanlık yerine oluşturulan Adalet Hak Komiserliği'ne Başsavcılık ve Yüksek Mahkeme doğrudan bağlanmıştır (Minjust, 2018).

1936 yılında Başsavcılık makamı bağımsız kılınmıştır. 1957 yılında ceza hukukunda ilk defa olarak "suçsuzluk karinesi" nosyonu kabul edilmiştir. 2004 yılında yayınlanan Başkanlık kararında, Rusya'da insan hakları ve medeni hak ve özgürlüklerin korunmasına yönelik faaliyetleri iyileştirmek ve hukuk devletinin gelişmesini sağlamak Adalet Bakanlığının görevi olarak tanımlanmıştır. Bunlardan başka, Bakanlık, uluslararası örgütlerin ve yabancı kar amacı gütmeyen örgütlerin, siyasi partilerin, dini örgütlerin ve derneklerin kaydını tutar ve bunlar hakkında bilgi sağlar, noterlik faaliyetlerini düzenler, medeni hal değişikliklerinin kaydını tutar, apostilelerin onayını sağlar, yozlaşma ile mücadele eder (Minjust, 2019).

Federal Cezaevleri İdaresi (FSIN) Cezaların infazı, tutuklu veya hükümlülerin cezai kontrol ve denetim alanında kolluk işlerini yerine getirir. Gözaltındaki sanıkların korunması, şartlı tahliye edilen mahkumların ve hükümlülerin davranışlarını denetleme faaliyetlerini de yürütür. Tutuklu ve hükümlülerin hak ve özgürlüklerini ve yasal menfaatlerini temin eder. Hükümlülere sosyal uyum desteği sağlar (Minjust, 2018).

Federal İcra Daireleri Adalet Bakanlığı bünyesinde yer almaktadır. Bazı adli işlemlerin yanında kolluk görev ve işlevlerini de yerine getirmektedir (Minjust, 2018).

\section{7. İçişleri Bakanlığı- MVD (MinisterstvoVnutrennih Del)}

Rusya İçişleri Bakanlığı (Ministerstvo Vnutrennih Del) yönetiminde çoğu sahada doğrudan vatandaşlarla ilişkide bulunan bir milyondan fazla personele sahip ülke çapında kolluk teşkilatını yönetmektedir. İçişleri Bakanlığı, ulusal, federe bölge ve 
ilçelerde benzer şekilde yapılanmış, uzmanlaşmış alt birimlerden oluşan hiyerarşik bir örgütlenme şeklindedir. Bu alt birimlerin her biri, trafik, suç araştırma, adi suçlar, yolsuzluk ve aşırılıkla mücadele gibi spesifik kolluk faaliyetlerini icra etmektedir. Rusya genelinde her birinde 100-150 personel bulunan yaklaşık 2000 yerel birim, yaklaşık 50.000 ile 100.000 nüfusa hizmet vermektedir (McCarthy, 2014: 5).

Rus polisinin davranışları genel olarak iki önemli kurumsal karakteristik tarafından belirlenir. İlki, katı hiyerarşik itaattir. Rus polisi herhangi bir yerel, bölgesel veya ulusal hükümet memuruna karşı veya halka karşı sorumlu değildir. Bütün sorumluluğu Bakanlık içinde ve dikeydir. Polis bağlı olduğu birimin hiyerarşik olarak federal düzeye kadar üstünde bulunan her kademesine karş1 sorumludur. Örneğin Sverdslovsk bölgesinde yer alan Ekaterinburg şehrindeki bir trafik polisi, kendi üzerindeki Sverdslovsk bölgesi polislerine karşı sorumludur; ancak aynı zamanda Ekaterinburg şehrindeki trafik polis amirine karşı da sorumludur. Sorumluluğu, Ekaterinburg şehrindeki, Sverdslovsk bölgesindeki ve Rusya Federasyonundaki federal düzeydeki amirlerinin tümüne karşı geçerlidir. $\mathrm{Bu}$ durum bazen bilgi verme yükümlülüğünde tekrarlanmalara yol açmaktadır. Aynı zamanda farklı hiyerarşi hatlarından gelen farklı talimatların nasıl değerlendirileceği konusunda da karışıklığa neden olabilmektedir. Katı hiyerarşik yap1, polis memurlarının ek ödenek veya tazminat almalarına karar verme yetkisinin amirlerde olmasına imkân sağlamıştır. Polis memurları ek ödenek ve tazminatları, kıdemlerine, rütbelerine ve geçim maliyetlerinin yüksek olduğu bölgelerde çalışmalarına göre almaktadır. Üst düzey amirler ise ek olarak çözülen suç sayısı ve işini iyi yapma kriterlerine göre de ödül verme yetkisine sahiptir. Amirini memnun edemeyenlerin ödül ve ek tazminat almaktan mahrum kalma riski söz konusu olmaktadır (age.7).

Polislerin performans değerlendirmesinde, kaydedilen suç sayısı, çözüme kavuşan suç sayısı vb. gibi istatistiksel veriler kullanılması da (paloçnaya sistema) polisin davranışlarını etkileyen bir diğer olumsuz etkendir. Bu sistemde üç ana kriter belirlenmiştir. Bunlardan ilki çözüme kavuşan vaka sayısıdır. Vakanın çözüme kavuşması, zanlının tanımlanması ve suçlanması ile gerçekleşir. İkinci kriter de vakaların kriminal süreç mevzuatınca belirlenen zaman içinde araştırılıp araştırılmadığıdır. Burada kural, suçun gerçekleşip gerçekleşmediğinin on gün içinde belirlenmesine yönelik araştırmadır. Ancak vakanın karmaşıklığı veya ne gibi soruların cevaplanması gerektiği gibi unsurlar dikkate alınmaz. Üçüncü kriter 
ise vakaların ve faaliyetlerinin sayılarının geçen yıllarla karşılaştırılmasıdır. $\mathrm{Bu}$ durum ise polis memurlarını vaka ve faaliyet sayıları konusunda daimi strese sokmaktadır. Paloçnaya sistemi aynı zamanda aşırı bürokratik işlem ve kırtasiyeciliğe sebep olmaktadır. Polis memurları vaka soruşturma işlemlerinin her aşamasında bilgisayara girmek ve her aşamayı kayıt etmek zorundadır. Moskova polis teşkilatında yapılan bir çalışmada polislerin mesailerinin \%80'ini evrak işleriyle geçirdiği gözlenmiştir (McCarthy, 2014: 6).

Rusya İçişleri Bakanlığının Teşkilat Yapısı şu şekildedir (MVD, 2019).

\section{İçişleri Bakanlığı Hizmet Birimleri}

- Karayolları Genel Müdürlüğü

- Kamu Düzeninin Sağlanması ve Rusya Federasyonu'nun Yürütme Organları ile Etkileşim Koordinasyonu Müdürlüğü Kamusal düzenin ve güvenliğinin sağlanması, suçun önlenmesi, vb. faaliyetleri yürütür. Kolluk teşkilatının ana unsurunu oluşturur.

\section{- Aşırılıkla Mücadele Müdürlüğü}

- Teşkilat İçi Güvenlik Müdürlüğü Polis teşkilat mensupları, çalışanların güvenliğini sağlama ve kurum içi yozlaşma ile mücadele.

- Ulaştırma Genel Müdürlüğü Kara, hava, deniz yolları nakliye ve ulaşım güvenliğinin sağlanması ve suçun önlenmesi.

- Ceza Soruşturma Genel Müdürlüğü Suçların tespiti, önlenmesi, bastırılması ve açığa çıkarılması faaliyetlerini yürütülmesi.

\section{- Ekonomik Güvenlik ve Yolsuzlukla Mücadele Müdürlüğü}

- Göç Müdürlüğü Ülke içi ve ülke dışı pasaportların verilmesi, denetimi, yabancı ülke vatandaşlarının ülkeye giriş, ikamet, çalışma ve davet izinlerinin denetimi.

- Uyuşturucu Kontrol Genel Müdürlüğü Her türlü uyuşturucu psikotropik maddenin denetimi, uyuşturucu ticaretinin önlenmesi.

- Soruşturma Dairesi Ön soruşturma, soruşturma, ceza soruşturması gibi faaliyetler.

- Personel Dairesi: İnsan kaynakları yönetimi, hizmet içi eğitim, yabancı ülke personeline eğitim verme, personel organizasyonu vb. faaliyetler.

- Arşiv ve Dokümantasyon Dairesi 


\section{- Bilgi Teknolojileri, İletişim ve Bilgi Koruma Dairesi}

- Mali ve Ekonomik Politika ve Sosyal Güvenlik Dairesi Kurumun bütçesinin yönetimi, çalışma ve emeklilik ödemlerinin yönetimi vb.

- Hukuk Dairesi Kamu düzeninin korunması, suçla mücadele gibi konularda analiz, çözüm ve stratejiler geliştirme faaliyetleri.

- "K"' Dairesi (Özel Teknik Önlemler Dairesi) K Dairesi, bilgi iletişim, internet ve benzeri teknolojik ortamlarda siber suçlarla mücadele eder ve internet üzerindeki suçların önlenmesi, küresel internet ağındaki vatandaşların güvenlik ve hukuki korunmasını ve iyileştirmeyi amaçlar. Bu amaç doğrultusunda şu önlem ve faaliyetlerde bulunur: Bilgisayar suçlarını önlemek amacıyla yetkisiz erişimin tespiti ve bastırılması, elektronik ödeme sistemlerinin istismar edilmesine karşı önlemler, internet yoluyla yasal olmayan pornografik materyallerin dağıtımının engellenmesi, hücresel telefon ağlarının yasadışı kullanımı ve suç amaçlı kullanımının belirlenmesi ve bastırılması, uydu ve kablolu televizyon ticari ağlarına izinsiz erişim girişimlerinin bastırılması, bilgi iletişim ortamlarında yasadışı ticaretle mücadele, telif hakk1 ve ilgili haklarının ihlalinin önlenmesi, bilgi teknolojileri alanında uluslararası suçlarla mücadele (MVD, 2018).

- Devlet Korumasına Tabii Kişilerin Güvenliği Dairesi Mağdur, tanık, hakimler, savcılar, müfettişler, kolluk ve düzenleyici otoritelerin korunması, koruma önlemlerinin geliştirilmesi.

- Sivil Toplum ve Medya ile İlişkiler Dairesi Bakanlığın faaliyetlerine bilgi desteğinin sağlanması, medya, bilgi ve iletişim sağları vasıtasıyla vatandaşları bilgilendirmek, Bakanlık faaliyetleri hakkında medya haberlerini izlemek ve analiz yapmak, Bakanlığın, medya, hükümet organları, kamu kurumları ile etkileşimini sağlamak, Bakanlığın basın hizmetleri, bilgi birimleri ve halkla ilişkiler faaliyetlerine kurumsal ve metodolojik destek sağlanması.

- Büyük Uluslararası ve Kitlesel Spor Etkinliklerinin Güvenliği Dairesi 2008 yılında kurulmuştur. Rus polis teşkilatının modernleşmesinde önemli katkılar sağlayan ancak yeterli önemi kazanmamış olan "Büyük

\footnotetext{
${ }^{2}$ Киберпреступность: Siber suçlar
} 
Uluslararası Spor Etkinlikleri ve Kitle Güvenliği Dairesi, 2014 Sochi kış olimpiyatları sırasında kamu güvenliği ve kamu düzeninin sağlanması için 2008 yılında kurulmuştur. Ancak 2011 yılında Asya-Pasifik Ekonomik İşbirliği Forumu ve 2013 Vladivostok ve Kazan'da Dünya Üniversitelerarası Yaz Olimpiyatlarında görev almış; en son olarak 2018 Rusya Dünya Futbol Şampiyonasında da görev almıştır.

Birimin Rus Polis Teşkilatının Modernleşmesinde kritik rol oynaması, Rus hükümetinin geliştirdiği kamu politikasında yatmaktadır. Uluslararası organizasyonlarda kamu idaresinin kapasitesinin de aynı düzeyde yüksek olması beklenir ancak polis teşkilatında özellikle 2010'lardan sonra yapılan genel ve tümdengelimci reformlar görece başarı sağlamıştır. Öte yandan belirli bir uluslararası kitle organizasyonu için somut kriterler ortaya koymak ve ilgili kamu idarelerini bu somut kriter düzeylerine ulaşmak için motive etmek daha başarılı sonuç vermiştir. 2014 Sochi kış olimpiyatları örneğinde, Sochi şehrindeki polis, gümrük, havaalanı, trafik vb. kurumların örgütsel yapıları, işleyiş̧leri, kapasiteleri, halkla ilişkileri, eğitimleri ve diğer ilgili kurumlarla koordinasyonlarında önemli gelişmeler kaydedilmiştir. Aynı durum 2018 Dünya Futbol Şampiyonası organizasyonunda da gözlenmektedir. Somut bir olay ve performans hedefleri belirlendikten sonra, hükümetin idari kurumları bu yönde motive etmesi daha kolay olmuş; bu hedeflere bir kez ulaşıldıktan sonra da geri dönmemesi ve daha da ileri götürülmesi için çalışmalar devam etmiştir. Kontrol edilecek küçük bir alan veya organizasyon ölçeğinde yapılan seferberlik niteliğinde reform çabalarında başarı elde etmek daha kolay olmakta; elde edilen kazanımların da ülke çapında İçişleri teşkilatına uyarlanması ve benimsenmesi daha az direnç ve zorlukla karşılaşmaktadır.

- Personel Müdürlüğü İçişleri Bakanlığının personel temini, geliştirilmesi, personel politikalarının oluşturulması faaliyetleri.

- Kontrol ve Revizyon Ofisi İç mali denetim faaliyetleri.

- Soruşturma Dairesi Birim, ön soruşturma, suçların tespiti, ifşası ve soruşturulması, cezai takibat faaliyetlerini düzenler. Suçun önlenmesi, tespiti, açığa çıkarılması faaliyetlerini yürütür, bu faaliyetler için gerekli organizasyonu sağlar, ilgili birimler arasında işbirliği düzenler. İçişleri 
Bakanlığının tüm birimlerinin ve kolluk kuvvetlerinin kullanımlarının, acil durumlarda öncelikle alanların belirlenmesi ve değerlendirilmesi faaliyetlerini yürütür. Acil durumlarda ve sıkıyönetim hallerinde operasyonel ortamlardaki değişiklerin yanı sıra kolluk güçlerinin hazırlanması, operasyonun hızlı tepki vermesinin sağlanması, nükleer maddelerin yasadışı ticaretiyle mücadele, kapalı bölgelerdeki tesislerin korunması için gerekli birimlerle işbirliği yapma gibi görevleri vardır.

\section{- İnterpol Merkez Dairesi}

- Yönetim Akademisi İçişleri Bakanlığına bağlı olan Yönetim Akademisi, Bakanlığın faaliyet alanları kapsamında yüksek öğretim, mesleki eğitim ve ek mesleki eğitim programları yoluyla eğitim hizmetleri verir ve bilimsel faaliyetlerde bulunur.

\section{- Adli Tıp Merkezi}

- Profesyonel Gelişim Enstitüsü Üst düzey personel yetiştirmek üzere lisansüstü programlar yürütür.

- Araştırma Enstitüsü Operatif soruşturma, ceza yargılaması, ceza hukuku, idare hukuku ve kriminoloji alanında bilimsel faaliyetler yürütür.

- İnformasyon ve Analiz Merkezi Parmak izi, operasyonel araştırma, istatistik, arşiv, bilimsel ve teknik bilgileri kolluk kuvvetlerine ve diğer kamu otoritelerine temin eder.

- Taşımacılık ve Malzeme Hizmetleri Merkezi İçişleri Bakanlığının bina, konut, lojman, giysi, araç gereç, motorlu taşıtların temini, yönetimi ve bakımı hizmetlerini sunar.

- Özel Taşımacılık Merkezi Kolluk kuvvetlerinin ve askeri taşıma işlerinin organizasyonunu gerçekleştirir.

- Özel ekipmanlar Özel ekipmanlar ve cihazlar üretme amaçlı bir araştırma enstitüsüdür.

- Köpek Eğitim Merkezi Kolluk güçlerinin kullandığı hizmet köpeklerinin yetiştirilmesi faaliyetini yürütür.

- Metroloji Merkezi İçişleri Bakanlığı bünyesindeki ölçümlerde standardizasyonu sağlamak, yangın güvenlik alarmlarının sertifikasyonunu sağlamak.

\section{- Trafik Güvenliği Merkezi}




\section{1991 - 2000 ARASI DÖNEM}

Sovyetler Birliği dağıldıktan sonra Rusya Cumhuriyeti 1991 yılında kuruldu. 1993 yılında kabul edilen Anayasa ile devlet "Rusya Federasyonu Cumhuriyeti" adını ald1. Ukrayna, Belarus, Gürcistan, Azerbaycan, Özbekistan, Kazakistan, Kırgızistan, Ermenistan gibi Sovyet Cumhuriyetleri bağımsızlıklarını elde etti. Ülkenin siyasi rejimi değişti. Komünizmden liberal demokrasiye doğru hızlı bir değişim yaşandı (ДАХИН, 2018). Bu çok boyutlu kökten değişim, tüm kamu yönetimine, özelde de iç güvenlik yapılanmasına da yansıdı.

Ancak 1990’lı yıllar Rusya için çalkantılı bir dönemin başlangıcıydı. İç güvenlik teşkilatlanması pek çok sorunla karşı karşıya kaldı ve etkinliğini önemi ölçüde yitirdi. Kamusal düzenin bozulması suç istatistiklerine de yansıdı. 1993 yılında 513.910 olan ağır suç sayısı, 1995 yılında üç mislinden fazla artarak 1.633.367'ye yükseldi. 1991 ile 1996 yılları arasında 550.000 ölümle sonuçlanan suç işlendi. Sadece 1992 yılında 213.590 kişi işlenen suçlar sebebiyle hayatını kaybetti (Semukhino ve Reynolds, 2012: 95).

1990’l1 yıllarda İçişleri Bakanlığı bünyesinde yapılan önemli düzenlemeler şu alanlarda oldu: adli kolluk ve kamu düzeni polisinin ayrılması, merkezi federal bütçeli ve yerel bütçeli polis birimlerinin ayrı teşkilatlanması, iç soruşturma departmanının kurulması, pasaport hizmetlerinin gözden geçirilip isminin değiştirilmesi (Гонюхов vе Горобцов, 2002: 86).

Ancak yapılan düzenleme ve reform çabaları düzelme sağlamaktan uzaktı. Polis hizmetlerinden memnuniyet düzeyi $\% 3$ ila $\% 25$ arasında oldukça düşük düzeyde kald1. Kolluğun güç istismarı ve yozlaşması, toplumda polis korkusunu arttırmıştı. $\mathrm{Bu}$ durumun bazı sebepleri şunlardı:

1- $\mathrm{Bu}$ dönemde İçişleri Bakanlığının yaptığı reform uygulamalarının polis sisteminde öngörülen değişikliği yapamadı. Kolluk teşkilatlarının halka kapalı, hiyerarşik, aşırı bürokratik ve askeri niteliklerinin değiştirilemedi.

2- Yeni sistem etkin bir iç denetim mekanizması getirilemedi. Sovyetler zamanında polis, Parti denetimi altında idi. Yeltsin, İçişleri Bakanlığı üzerindeki Parti denetimini kaldırdığında siyasileşmenin de biteceğini düşünmüştü. Ancak teşkilat bakan vasıtasıyla siyasete bağlı kaldı.

3- 1990'ların başlarında yasal boşluklar ve kaos, polis için oldukça sorunlu bir dönem yaratmıştı. Sovyet yasaları, idari komuta ekonomisi için yapıldıklarından, yeni dönemde işlevsizdi. Yeni liberal ekonomiye zemin 
sağlayacak çok az yasal düzenleme yapılabilmişti. Bazı zararlı davranışların yasal dayanağı olmadığı için soruşturulması mümkün olmuyordu. Mevzuatta çok fazla gri alanlar oluşmuştu.

4- Ceza yargısının demokratikleşmesi çabalarında sanıklara ilave haklar sağlandı. Sanıklar avukata danışma ve tutukluluklarına mahkemede itiraz edebilme hakkı kazandı. Bazı davalarda jüri sistemi getirildi. Soruşturmacı kolluk, sanıklara hak tanıyan yasalara uyum sağlayamadığından çoğu zaman tereddüte düşüyor ve suç takibini gereğince yapmakta çekince yaşıyordu.

5- Maaş ödemelerinin devamlı olarak gecikmesi, dosya yüklerinin gittikçe artmas1, güvenlik sorunlarının artması gibi nedenlerin yarattığ1 stres, personelde moral bozukluğu yaratıyor ve suç çözümleme istatistiklerinde dramatik düşüşlere yol açıyordu. Deneyimli personel daha yüksek ücret ve daha düşük stresli özel sektöre geçiyorken yeni personel eğitim ve deneyim bakımından zayıftı.

6- 1980'ler boyunca gelişen organize suç hükümete ve kolluk teşkilatına sızmaya başlamıştı.

Bütün bu unsurlar, kolluk teşkilatında demokratik yasal reformların başarısız olmasına yol açmaktaydı (Semukhino ve Reynolds, 2012: 98).

\section{PUTINN DÖNEMİ, 2000 VE SONRASI ${ }^{3}$}

Yeltsin'in görevden ayrılıp yerine Vladimir Putin'i önermesi ile günümüze kadar devam eden Putin dönemi 2000 yılında başladı. 1991 yılında Rusya Cumhuriyetinin ilk başkanı olan Yeltsin, 1999 sonuna kadar olan iktidarı süresince Batı tarzı modernleşme tercihiyle ülkede Batılı demokratik bir rejim ve idari teşkilatlanma çabalarına girişmişti. Ancak bu kısa dönemde ülkenin ekonomik, siyasi, sosyal ve kültürel anlamda batılı örneklerine ayak uydurması mümkün olmadi.

Ülkede Batının demokratik yapısı, ekonomisi, idari ve siyasi teşkilatlanması ve işleyişi ile ilgili bilgi ve deneyimi olan yoktu. Total değişimi yapacak olan siyasi liderler Sovyet Dönemi devlet adamlarıydı. Neyi nasıl yapacakları hakkında çok az bilgileri vardı. Ülkede ne sivil toplum kuruluşları ne liberal ekonomi aktörleri ne demokratik siyasi kuruluşları ne batı demokrasileri literatürüne vakıf üniversite ve bilim adamları vardı. Batılı sivil ve resmi danışmanlık kuruluşlarının desteği çok

\footnotetext{
3 2000'den sonrasının Putin dönemi olarak adlandırılması, literatürde geniş kabul görmüştür. Rusya Anayasasına göre Devlet Başkanı arda arda iki defa görev yapabilir. Bu kısıt Medvedev ile başbakanlık ve devlet başkanlığının yer değiştirmesiyle aşılmakta ancak devlet yönetiminde Putin'in baskın rolü devam etmektedir.
} 
etkili olmadı (Дахин, 2018a: 185). Üstelik ülkede kıtlık, sefalet, ayrılıkçı hareketlerin yol açtığı silahlı çatışmalar hüküm sürüyordu.

Kötü de olsa eski sistem yıkılmış ama yerine yeni bir sistem ve düzen kurulamamıştı. En kötü düzenin, düzensizlikten ve kaostan daha iyi olduğunu kanıtlarcasına yoksulluk, suç ve sefalet olağanüstü derecede arttı. Kamu kurumları işlevlerini yerine getiremez hale geldi. Parçalanma tehlikesi yaratan iç etnik çatışmalar baş gösterdi. Asayiş ve güvenlik kalmadı. Suç oranları büyük ölçüde artt1.

2000 yılından itibaren Putin'in dönemi başladığında da girişilen reform faaliyetlerinde kısa dönemde başarılar elde edilemedi. Bu dönemde de birbiri ardına reform program ve planları uygulanıyor ama çok az başarı elde ediliyordu. Ayrıca Putin başta Çeçenistan olmak üzere ülkedeki iç savaş sorunlarıyla da baş etmek zorundaydi.

2000'li yıllarda Rus iç güvenlik yapısına yönelik çok sayıda reform teşebbüsü yapılsa da günümüz güvenlik yapısını belirleyen etkili reformlar Putin'den sonra Devlet Başkanı olan Medvedev tarafından gerçekleştirildi. Medvedev, 2009 ve 2011 yılları arasında iç güvenlik teşkilatlanmasına yönelik bir dizi reform gerçekleştirdi ve bu reformlar günümüz Rusya'sının kolluk yapılanmasını şekillendirerek önemli ölçüde başarılı oldu.

2009 yılındaki polis reformları, Rusya'da kamu yönetiminin her kademesinde yozlaşmayı temizlemeye yönelik genel reformun bir kısmını oluşturmuştu. 2009 yılında çıkan "Polis Yasası" kolluk güçlerinin faaliyetlerini düzenlemeyi, İçişleri Bakanlığının meşruluğunu ve etkinliğini geliştirmeyi amaçlamıştı. Ancak bu Yasa, reform yürütücülerinin açı bir vizyonu olmaması, nasıl başarılacağına dair bilgilerinin ve yeterli desteğin sağlanamaması sebebiyle bekleneni veremedi (Cheloukhine, 2017: viii).

2000'li yılların başında yozlaşma Rus kamu yönetimi teşkilatının her tarafına işlemişti ve etkileri toplumda derin bir şekilde hissediliyordu. 2015 Şeffaflık Örgütü İndeksine göre Rusya 176 ülke içinde 119. sıradaydı. Rusya İçişleri Bakanlığı Ekonomik Suçlarla Mücadele Departmanına göre 2008 yılında ortalama rüşvet miktarı 9.000 Ruble, 2009 y1lında 23.000 Ruble ve 2012 y1lında da 236.000 Ruble /yıl miktarına ulaşmıştı (Cheloukhine, 2017: viv).

Yozlaşmayla mücadelede 2009 yılının ilk altı ayında 4.500'den fazla yolsuzluk davası açıldı; 532 kamu görevlisi ve 700'den fazla kolluk görevlisi tutuklandı. Öte 
yandan aynı yıl kolluk maaşları iki mislinden fazla arttırılarak ortalama 300 Amerikan dolarına denk gelecek şekilde yükseltildi. Organize suç örgütleriyle ilişkisi bulunanlar görevden çıkartıldı; personel sayısı \%30 azaltıldı. Ulaşılabilen istatistik rakamlarıyla ${ }^{4} 1994$ yilında Ceza Yargilama Sisteminde 1.800.000 olan personel sayısı, 2009 yılında 1.400.000'e düştü.

Medvedev'in yaptığı ikinci önemli reform, 2011 yılında kolluk teşkilatını Militsia'dan Polis'e dönüştürmesidir. Bu reformla kolluk teşkilatının denetimi daha merkezileştirildi, denetim yetkileri bakımından yerel ve belediye yetkileri kaldırıldı ve doğrudan Moskova'ya, İçişleri Bakanlığının yetkisine verildi. Aynı zamanda Cezaevlerinin sorumluluğu İçişleri Bakanlığından alınarak Adalet Bakanlığına, itfaiye teşkilatı da Acil İşler Bakanlığına devredildi.

2011 yılındaki “İçişleri Bakanlığı Hakkında” Başkanlık Kararı, İçişleri Bakanlığının yeni görevlerini, örgütsel yapısını ve Bakanlığın toplam personel sayısını belirliyordu. Karar, 2014 Sochi Kış Olimpiyatlarının güvenliğine yönelik uluslararası ve kitle spor organizasyonlarına dair yeni birimler de öngörüyordu ${ }^{5}$. Aynı tarihli takip eden Karar'da ise İçişleri Bakanlığının bölgesel teşkilatlanmasına yönelik standartlaşma, taşra teşkilatlanmasında ise oldukça detaylı sorumluluk ve örgütsel yapılanma tanımlamaktaydı. 2011 yılında Militsia'dan polis teşkilatına geçildiğinde her bir personel yozlaşma suçlarına karışıp karışmadığı bakımından incelendi ve Personelin suça karışmadığına dair "temiz sertifikası" aldıktan sonra polis teşkilatına transferi tamamlandı. Polis maaşları tekrar arttırıldı (Semukhina, 2014: 2).

$\mathrm{Bu}$ dönemde ortalama maaşlar 1000 Amerikan doları civarına yükseltildi ve maaşlar gecikmeler olmaması için merkezi bütçeden ödenmeye başlandı. Yozlaşmanın ve etkinsizliğin en büyük içsel nedenlerinden olan düşük maaş sorunu böylelikle ortadan kaldırıldı. İçişleri Bakanlığı 2011 yılının Mart ve Ağustos ayları arasında bütün polis memurlarını ayrı ayrı denetledi. Kolluk personelinin \%90’1

\footnotetext{
${ }^{4}$ 1990'lı yıllar ve 2000'li yılların başında Rusya'da istatistiki bilgiler sağlıklı tutulamamıştır. Yer yer boşluklar vardır ve kayıtlardan elde edilen veriler sağlıklı değildir.

${ }^{5}$ Sochi Kış Olimpiyatları uluslararası nitelikteydi. 2011 Kararları da Olimpiyatlar odağında kolluk hizmetlerinin uluslararası düzeye getirilmesini amaçlamaktaydı. Etkinsizlik, yozlaşma gibi eski hastalıklar, Olimpiyatlar esnasında olmamalıydı. 2014 Olimpiyatları motivasyonu ile ulaşılan polislik standartları, sonrasında büyük ölçüde korundu ve ülkenin diğer bölgelerine de yayıldı. Kolluk faaliyetlerinde elde edilen bir diğer büyük gelişmenin ise 2018 Futbol şampiyonasında gözlemlendiği kamuoyu ve basın tarafindan dile getirilmektedir.
} 
(875.000), idari personelin ise \%94'ü bu denetimden başarılı çıktı ve görevlerinde kaldılar.

Aynı reform çerçevesinde İçişleri personelinin değerlendirme ve terfi sistemi de geliştirildi. O zamana değin var olan sistem, kayıtlı suç sayısı ile tutuklanan zanlı sayısının oranlanmasına dayanmaktaydı ve bu durum, verileri manipüle etme ve güç istismarına yol açmaktaydı. Kolluk görevlileri performans hedeflerine ulaşmak için çözülmesi zor olan suçları kayıt etmekten kaçınıyorlardı veya suçsuz olan vatandaşlara dahi zorla suç itiraf ettirme yöntemlerine başvuruyorlardı. Performans değerlendirme süreçlerinde bu tür istatistiklerin kullanılması kaldırıldı (Semukhina, 2014: 2).

2011 reform yasalarının hazırlanması esnasında da demokratik ve şeffaf yöntemler izlenmiş olması dikkat çekicidir (Зайцева, 2016: 180). Yasa tasarıları internet vasıtasıyla kamuoyu tartışmalarına ve görüş önerilerine açıldı. İnternet ortamında vatandaşlardan 20.000'in üzerinde yorum, katkı, eleştiri ve değerlendirme sağlandı. Pek çok Rus ve Uluslararası sivil toplum kuruluşu, üniversiteler ve ilgili kamu idareleri çalışmalar düzenledi ve yayınlarda bulundu. Tartışmalar sürecinde vatandaşlar kolluk uzmanları ve medya etkisi fazla olmasa da özgürce polis reformu hakkında eleştiriler yapabildiler (Semukhina, 2014: 3).

2013 yılında Federal Hükümet, yeni bütçe programında 2014-2020 yılları arasında kolluk teşkilatına 255 milyar dolar gibi büyük bir mali kaynak tahsis ettiğini açıkladı. Bu tahsisin hedeflerinin kayıtlı suç sayısının düşürülmesi, suçların çözülme oranlarının arttırılması, kamuoyunda güvenin ve hizmetlerden memnuniyet derecelerinin artması olduğu belirtildi. Kolluk teşkilatında merkezileşme reform hedeflerinden olduğu için ilçe bazında polis birimlerinde azaltılmaya gidildi.

2011-2014 polis reformlarının önemli kazanımlar sağladığı söylenebilir. Rusya' da "kötü polis" imajının ortadan kalktığı kabul görmüş bir değerlendirmedir. $\mathrm{Bu}$ dönemde polis teşkilatı hakkındaki tartışmalar gündemden düştü ve sıradanlaştı. Reformların bir diğer başarısı da polis memurları arasında mesleki tatmin düzeyinin artmasıdır. Bir taraftan bazı polis memurları "sertifikalandırma" süreciyle sıkı bir kişisel denetimden geçmekten ve kamuoyu denetiminin artmasından şikayetçi olsalar da, artık terk edilmiş hissetmedikleri ve hükümet tarafından hatırlandıkları ve özlük haklarının eskiye göre çok daha iyi olduğu düşüncesi ağır basmaktadır (Semukhina, 2014:4). 


\section{2010 SONRASI DÖNEMDE KOLLUK TEŞKILLATINDA MODERNLEŞME}

Sovyetler Birliği sonrası pek çok reform çabaları olmasına rağmen, günümüz modern polis yapılanmasının başlangıcı esasen 2011 Medvedev reformlarına dayanmaktadır. 2011 yılında çıkan "Polis Yasası" eski Çarlık ve Sovyet polis anlayışını değiştirme iradesini somut olarak ortaya koyan bir metindir. 2011 Polis Yasası temel olarak kolluk teşkilatının etkinliğini arttırmak, yozlaşmayı azaltmak ve kamuoyu imajını düzeltmeyi amaçlamıştır.

Polis reformu sürecinde personel sayısında $\% 20$ oranında azalmaya gidildi, bütün kolluk teşkilatı "sertifikasyon" sürecinden geçerek, her bir personel suç, yozlaşma ve organize suç örgütleriyle ilişkiler bakımından incelendi, maaş ve diğer maddi imkanları önemli derecede arttırıldı. Örgütsel yapıda dağınıklık giderildi ve teşkilat merkezi yapıya kavuşturuldu.

\subsection{Polis Reformunun Ana Unsurları}

-İsim Değişikliği: Reform ile Rus kolluk teşkilatının ismi Sovyet dönemi "Militsia" değiştirilmiş; daha evrensel bir kavram olan "Politsiya" (Polis) benimsenmiştir.

-Personel azaltılması ve Ücretlerin arttırılması: kolluk personelinin sayısı \%20 azaltılarak 1.280.000'den, 1.100.000'e düşürüldü. Ancak daha sonra "sertifikasyon" süreciyle suça ve yozlaşmaya bulaşmış kolluk görevlileri de görevden çıkarıldı. Polis maaşları süreç içinde 1000 Amerikan dolarına kadar çıkarıldı. Eski sistemde polis birimlerinin basit ve küçük suçlar için yetki alanları bölgesel veya şehir idareleri çapındaydı; yerel bütçelerden finansmanı sağlanıyordu ve daha çok yerel otoritelere karşı sorumluydu.

-Kamuoyu Algısının Düzeltilmesi: Çarlık ve Sovyet dönemi polisinin halk nazarında algısı çok olumlu değildi. Polisle ilişkide bulunmanın kişilere zarar vereceği algısı yerleşmişti. Mağdur olanların dahi polise başvurduklarında ayrıca polisten kötü muamele, fiziki şiddet, rüşvet, suçlunun kayırılması gibi ayrıca zarar görme olasılığı yüksekti. Önceki dönemlerde polis, vatandaşı korumaktan çok, iktidarı ve ideolojiyi koruma görevini ön planda tutuyordu. Reform bu kötü algıy1 değiştirmeyi amaçlamıştır. "Polis faaliyetlerini insan hak ve özgürlüklerine saygılı olarak yürütür. Vatandaşların hak ve özgürlüklerini kısıtlayan polis faaliyeti meşru hedefe ulaşınca durum derhal sona erer. Polis memurunun işkence, şiddet ve diğer zulüm ve aşağılayıcı davranışlarda bulunması yasaktır." İfadesi, bu amaca vurgu yapmaktadır. Yasada polisin faaliyet ilkeleri belirtilirken insan haklarına sivil hak ve özgürlüklere riayet ve saygı prensibi eklendi. Polisin görevini yaparken 
ayrımcılık yapması da yasaklandı. Cinsiyet, 1rk, milliyet, dil, köken, mülkiyet ve resmi statü, din, sabıka vb. gibi niteliklere göre vatandaşlar arasında ayrımcılık yapması yasakland1 (Md.5).

Ayrıca İçişleri Bakanlığı bünyesindeki bilim ve eğitim kuruluşları devamlı olarak halkın polis algısındaki değişimi ölçmeye, bu yolla elde edilen verileri, eksiklik ve zayıflıkları gidermekte kullanmaya başladı. Anket ve araştırma sonuçlar İçişleri Bakanlığının sitesinden düzenli olarak yayınlandı (MVD, 2018).

Polis teşkilatı kamuoyu desteğini geliştirmek amaciyla sivil toplum kuruluşlarıyla da işbirliğine girişti. St. Petersburg'da "Vatandaş Kontrolü" adlı STK'lar, insan hakları düzeyinin gelişimi için polis eğitimi faaliyetlerine katılmaya başladı. Nijni Novgorod şehrinde "Adalet Desteği” adlı sivil toplum kuruluşu, polis merkezlerinde vatandaşların polisle ilişkiye girmeden önce ilk başvuracağ kontak" masaları oluşturdu. Polis merkezine gelen vatandaşlar, şikâyet, işlem vb. gibi süreçlerde önce bu masalardaki STK uzmanlarıyla görüşüyorlar, hukuki bilgi ve destek alıyorlar, akabinde ya kendileri veya kendileri adına STK mensupları polisle iletişime geçiyordu. Bu şekilde kamuoyunda polise karş1 vatandaş güveninin arttırılması planlanmaktaydı (Taylor, 2018:7).

Rusya İçişleri Bakanlığının arşivlerinde suç istatistikleri 2003 yılından itibaren tutulmaya başlanmıştır. Daha önceki zamanlara dair suç kayıtları farklı kaynaklarda bulunabilmekle birlikte güvenilirliği ve karşılaştırılabilirlik açısından sağlıklı bilgi vermekte yetersiz kalmaktadır. İstatistiklerde görüldügü üzere Rusya'da suç oranları 2006 yılından itibaren istikrarlı bir şekilde düşmektedir. Ayrıca tabloyu daha sağlıklı yorumlayabilmek için suç kayıtlarına etki eden bazı durumsal şartları da göz önünde bulundurmak gereklidir. 2000'li yılların başlarında suç mağduru vatandaşların polise bildirimde bulunmaktan çekindikleri bir vakadır. Vatandaşlar çoğu zaman, hırsızlık, basit saldırı ev hırsızlığı vs. suçlarda polise bildirme konusunda daha isteksizdi. Öte yandan polis de suçları kayda almakta o kadar istekli değildi (Cheloukhine, 2017a: 14). Özellikle 2011'den sonra ard arda yapılan polis reformları hem vatandaşların polisten çekinmesi sorununu gidermiş, hem de polisin suç kaydı yapma isteksizliğinin nedenleri önemli ölçüde giderilmiştir. Polis- halk iletişiminde önemli ilerlemeler sağlanmıştır. Bu durumda 2003 yılı istatistiklerinin gerçek suç sayısını daha düşük gösterdiğini; 2017 yılındaki kayıtlı suç sayısında ise çeşitli nedenlerle bildirilmeyen suç sayısının daha az kaldığını düşünmek mümkündür. Bu unsurlar göz önüne alındığında suç sayısının istatistiklerin gösterdiğinden daha hızlı bir şekilde düştügünü söylemek mümkündür. 
Tablo.2 Rusya'da Yıllara Göre Suç Sayısının Değişimi (MVD, 2018a).

\begin{tabular}{|c|c|}
\hline YIL & KAYITLI SUÇ SAYISI $^{6}$ \\
\hline 2017 & 2.058 .476 \\
\hline 2016 & 2.160 .000 \\
\hline 2015 & 2.388 .500 \\
\hline 2014 & 2.166 .400 \\
\hline 2013 & 2.206 .200 \\
\hline 2012 & 2.302 .200 \\
\hline 2011 & 2.404 .600 \\
\hline 2010 & 2.387 .469 \\
\hline 2009 & 2.944 .000 \\
\hline 2008 & 3.209 .900 \\
\hline 2007 & 3.582 .500 \\
\hline 2006 & 3.855 .400 \\
\hline 2005 & 3.554 .700 \\
\hline 2004 & 2.893 .800 \\
\hline 2003 & 2.756 .400 \\
\hline
\end{tabular}

\section{KAMUOYUNDA POLIS ALGISI}

1990'lar ve 2000'lı yıllar boyunca Rus vatandaşlarının polis algısı oldukça olumsuzdu. 2010 yılina kadar polis hizmetlerinden memnuniyet oranlar1 \%50'nin altında seyretmiştir. 1990 ila 2010 yılları arasında Rus vatandaşlarının polise olan güven hissi \%11 ila \%45 arasında seyretmiştir (Semukhina ve Reynolds, 2012: 165). 1990 yılında yapılan bir araştırmada Rus polisi "kültürsüz, kaba, ilgisiz, yozlaşmış, sahtekâr ve rüşvetçi” olarak tanımlanmıştır (Мазаeв, 1997). Ancak araştırmalar, emekli, kırsalda yaşayan ve az eğitimli kişilerin polise güven duygularının daha yüksek olduğunu göstermektedir. Bazı araştırmacılar bu eğilimi, bu kesimdeki insanların daha korumasız kimseler olmaları sebebiyle polise güvenmek zorunda olmaları ile açıklamaktadır. Bu bireyler kendilerini koruyacak başka seçeneklere sahip değildirler. Ancak yine de en zayıf olanları dahil, herhangi bir nüfus grubunun üst düzey memnuniyet sergilediği gözlenmemektedir. Polise güven ve memnuniyet hisleri diğer ülkelerle karşılaştırıldığında dramatik oranda düşüktür. 1992-2002 yılları arasında karşılaştırmalı bir çalışmada Rusya'da polis memnuniyeti \%24.7 iken, bu oran Kanada'da \%84.6, Amerika'da \%83.9,

\footnotetext{
${ }^{6}$ Kayıtlı suç sayısı, İçişleri makamlarına ulaşan ve suç olarak kaydedilen vaka sayısıdır. Hakkında ceza davası açılan suç sayısı daha azdır. Öte yandan İçişleri makamlarına farklı kanallardan gelen çok sayıda şikayet ayıklanarak suç kaydı yapılmıştır. Örneğin 2006 yılında İçişleri birimlerine çeşitli kanallarla 19.300.000 şikayet ulaşmış; bunların 3.855.400'ü için suç kaydı yapılmış, bu suçlardan 3.262.600'ü için ceza davası açılmıştır. Rusya İçişleri Bakanlığının Suç istatistikleri 2003 yılından itibaren başlamaktadır.
} 
İngiltere'de \%70.1 ve Almanya'da \%66.7 olmuştur. Bu güvensizliğin sonucu olarak suç mağdurlarının polise başvurma oranlarında önemli düşmüştür. 1996 ve 2000 yılları arasında hırsızlığa maruz kalanların yarısından daha azı polise başvurmuştur (Semukhina ve Reynolds, 2012: 177).

Halkın polise karşı güvensizliğinin bir diğer sonucu da toplumda suç korkusunun yüksek olmasıdır. 2000'li yıllara değin resmi suç oranları arttıkça, suça uğrama korkusunda da artış olmuştur. Kamusal güvenin düşüklüğü, halk - polis işbirliğini de etkilemektedir. Bunun en büyük göstergesi, suç mağdurlarının polise başvurmayı reddetmesidir. 1992 ila 2000 yılları arasında dolandırııılık suçuna maruz kalanların ancak \%5'i polise şikayette bulunmuştur (Макарова, 2011: 64).

Sovyet dönemi ve Rusya'nın ilk yirmi yılı boyunca polisin halk gözündeki algısı oldukça olumsuzdu. Medvedev'in 2009 yılında giriştiği reform hamleleri bu sorunun da çözülmesine odaklanmıştı. Polisin imajını ve güvenilirliğini düzeltmek amacıyla eğitim faaliyetleri, bağımsız iç denetim örgütlenmesi, yasal düzenlemeler, personele yönelik yaptırımlar uygulamaya kondu. 2011'den itibaren nisbi de olsa polise duyulan güven ve imaj konusunda gelişmeler kaydedilmeye başlandı.

2011 yılında polise güven duyanların oranı \%52'den $2012 \% 54$ 'e çıkmıştır (VTsiOM, 2018). 2010-2014 yılları arasında polise güvenen ve olumlu bulan vatandaş oran1 \%52'den \%66'ya yükselmiştir. Nüfusun \%51'i ise son iki yılda (2012-2014 dönemi) hayatın daha güvenli olduğunu ifade etmiştir. 2014 yılında hayatın daha güvenli olduğunu düşünenlerin oranı \%54'e yükselmiştir. En son 2017 yılında yapılan araştırmada ise polisin algısında önemli gelişmeler olmuştur. 2017 y1lında polise olan güven vatandaşların \%67'sine ulaşmıştır. Güvensizlik oranı ise \%27'ye düşmüştür. Halkın olumlu algılama kriter değerlerinde de gelişmeler söz konusudur. Toplumun \%66's1 polisin nazik, \%66's1 dostça, \%65'i dürüst, \%65'i cesur ve \%64'ü ise yeterli olduğunu düşünmektedir. Bu olumlu alg1 değişimi, halkın polisle işbirliği isteğine de yansımıştır. 2017 yılında halkın \%90’1 tanık olmaya, \%74'ü ise işbirliği yapmaya gönüllü olacaklarını ifade etmiştir (MVD, 2018a).

Polis ve sanık haklarında değişim Yeni, yasada sanıklar tutuklandıktan üç saat içinde telefon etme hakkını elde etti. Polise sanıkları tutuklarken hak ve yükümlülüklerini bildirme zorunluluğu getirildi. Ticari müesseselerin mali ve ticari aktivitelerini inceleme hakkı polisten alındı. Polislerin vatandaşları kimlik belirlemek için bir saatten fazla alıkoymaları yasaklandı. 
Yozlaşmayla mücadele Polis teşkilatında yozlaşmayla mücadele amacıyla sıkı tedbirler uyguland1. Hemen hemen tüm polis görevlileri yozlaşma boyutuyla sıkı denetimden geçirildi (Polislerin \%90'1; idari personelin \%94'ü (Semukhina, 2014:2). Şüpheli, mağdur ve polis ilişkileri, rüşvet veya diğer istismarları azaltacak şekilde sıkı prosedürlere bağlandı.

Polisin faaliyet alanları Çarlık ve Sovyet polisinde, polisin vazifeleri arasında Çar'ın, Partinin ve ideolojilerin menfaatlerini korumak da sayılmaktaydı. Sovyetlerden sonra bu tür görevler kaldırıldı. Reform yasasıyla polisin ana faaliyet alanları şu şekilde düzenlendi:

1) Bireyin, toplumun ve devletin hukuka aykırı saldırılardan korunması

2) Suçların ve idari suçların önlenmesi ve bastırılması

3) Suçların tanımlanması ve ifşa edilmesi, ceza davalarında soruşturmaların yürütülmesi

4) Kişilerin aranması

5) İdari suçlarda idari cezaların uygulanması

6) Halka açık yerlerde yasa ve düzenin sağlanması

7) Trafik güvenliğinin sağlaması

8) Silah kaçakçı1ığının önlenmesi

9) Özel dedektif ve özel güvenlik faaliyetlerini denetlenmesi

10) Sözleşme esası da dahil olmak üzere mülkiyet ve eşyaların korunması

11) Ceza davaları, yargıçlar, savcılar, soruşturmacılar, kolluk kuvvetleri ve denetleme görevlileri ve diğer korunan kişilerin, mağdurların, tanıkların ve diğer kat1lımc1ların korunması

12) Uzman- kriminalistik faaliyetler.

Merkezileşme Reform sonucu polis teşkilatında federe ve bölgesel örgütlenmeler kaldırıldı ve Federal düzeyde bir kurum halinde tüm ülke çapında örgütlendi. 


\section{SONUÇ}

Rusya 1990'lı yılların başından itibaren içine düştüğü türbülans ve kaos ortamında liberal demokratik devlet ve yönetim biçimine dönüşüm çabalarında önemli başarılar elde etmiştir. Öte yandan kamu yönetimi teşkilat yapısı ve işleyişinde de köklü dönüşüm süreci içine girmiştir. $\mathrm{Bu}$ sürecin asli bir parçası olarak Kolluk yapısında da değişim sürecine girmiştir. Ancak 1990'lı yıllarda girişilen reform çabaları başarılı sonuçlar vermemiştir. 2000'li yıllardan itibaren Putin-Medvedev ikilisiyle siyasi istikrarın oluşmasından sonra reform süreçleri etkin bir şekilde sürdürülmüştür. Bu süreçte istikrarlı ve kararlı bir siyasi irade, kamuoyu desteği ve Rusya ekonomisindeki gelişmelerin desteğiyle kolluk teşkilatında reform çabaları başarılı sonuçlar vermeye başlamıştır.

Özellikle 2010 yılında Medvedev önderliğinde siyasi iradenin kararlı tutumu ve kamuoyu desteğiyle oldukça çarpıcı başarılar elde edilmiştir. Bir defa toplumun en temel gereksinimi olan kolluk hizmetleri alanında güvenlik, asayiş ve huzuru belli derecede başarı sağladığında, siyasi istikrar, ekonomik gelişme ve sosyal bütünlüğün başarılabileceği Rusya örneğinde görülmektedir.

1990'lardan itibaren Rusya'daki dönüşüm süreci halkın tamamen edilgen olduğu, tüm kararların Parti-Devlet elitleri tarafından alındığı ve kamu hizmetlerinin toplum tarafından asla sorgulanamaz bir bürokrasi egemenliğinde sunulduğu bir anlayıştan, liberal-demokratik yapıya dönüşümü içermektedir. Vatandaşların denetleyemediği, karar alma ve hizmet sunma süreçlerine katılamadığı bir kamu yönetimi teşkilatının sağlıklı bir şekilde yapılanması, işlemesi ve hizmet sunması mümkün değildir.

Rusya kolluk teşkilatının varlık nedeni de güvenlik hizmeti sunduğu Rus vatandaşlarıdır. Kolluk teşkilatında 2010'lu yıllara kadar yapılan reform çabalarında istenen başarıların elde edilememesinin başlıca sebebi de kamuoyunun görüş, talep ve şikayetlerinin hesaba katıldığı bir kamu politikasının geliştirilmemiş olmasıdır. Ancak 2010 yılından itibaren kolluk hizmetlerinin geliştirilmesi çabalarında kamuoyunun görüş ve kanaatleri de dikkate alınmaya başlandıkça kolluk hizmetlerinin kalitesi artmaya ve vatandaş memnuniyet düzeyleri yükselmeye başlamıştır. $\mathrm{Bu}$ doğrultuda yapılan kritik bir değişiklik kolluk hizmetlerinin performans ölçümünde kayıtlı vaka istatistikleri yoluyla değerlendirmenin (paloçnaya sistema) terk edilmesidir. Kayıtlı vaka oranının düşmesini başarı olarak gören bu yöntem, kolluğun vatandaşlardan gelen ihbar ve şikayetleri kayıt etmeme, istatistikleri karartma, basit hırsızlık, gibi suçları işleme 
koymama gibi olumsuz davranışlara yönlendirmektedir. Aynı şekilde çözülmesi güç ve failin bulunmasının zor olduğu vakaları da kolluk işleme koymakta isteksiz olmaktadır.

Paloçnaya sistemin terk edilmesi ve performans değerlendirmede vatandaş memnuniyetinin esas alınmasıyla kolluk reformunun başarılı olması, sağlıklı örgütsel düzenlemelerin yapılabilmesi, kolluk hizmetlerinin etkin ve verimli şekilde sunulması ve en önemlisi vatandaş- polis ilişkisinde olumlu gelişmeler sağlanması çok daha kolaylaşmıştır. Öte yandan gerçekçi olmayan performans değerlendirme kriterlerinden kurtulan kolluk görevlileri de kamuoyu algısı ve vatandaş memnuniyetine dayalı değerlendirme kriterlerini gözeteceğinden görevini daha motive olmuş bir şekilde yapabilmekte, mesleğinden aldı̆̆ manevi tatmin artmakta ve etkin ve verimli bir çalışma ortamına sahip olmaktadır.

Kolluk reformu sürecinde kamuoyu algısının önemini vurgulayan bir diğer göze çarpan olgu, kamuoyu ölçümleri yapan enstitünün (VTsiOM) tarafsızlığı ve güvenirliğinin sağlanması için tutarlı siyasi irade gösterilmiş olmasıdır. Bu amaçla kolluk hizmetlerinden memnuniyet düzeylerinin ölçümü İçişleri Bakanlığının dışında bağımsız bir enstitü olan VTsiOM tarafından yapılmakta, anket, sms mesajı gibi uygulamalar esnasında vatandaşlar değerlendirme sürecinin tamamen tarafsız ve mahremiyet haklarının da güvence altında olduğu konusunda temin edilmektedir. Böylece kolluk teşkilatı ve işleyişi hakkında vatandaşlardan sağlıklı geri bildirimler alınarak eksikler, hatalar, geliştirilmesi gereken unsurlar ve başarılar sağlıklı bir şekilde tespit edilebilmektedir. Rusya'da 2010'lardan itibaren kamuoyu algısında memnuniyet dizeylerinin dramatik bir şekilde yükselmesi çarpıcı bir gelişmedir.

$\mathrm{Bu}$ tür bir kamu politikasının siyasi iktidar açısından da iki boyutlu getirisi olmaktadır. İlki yönetmekle sorumlu olduğu kamu idaresi hakkında sağlıklı bilgi ve geri bildirim elde ederek, o idarenin daha iyi yönetilmesi mümkün olmaktadır. İkincisi ise kamu hizmetlerine yönelik kamuoyu algısının iyileşmesi siyasi destek ve oy potansiyelini arttırmaktadır. 


\section{KAYNAKÇA}

Agentura (2018) Служба безопасности Президента Российской Федерачии, http://www.agentura.ru/dossier/russia/fso/sbp/structure/ (20.9.2018).

Baharçiçek, A. ve Ağır, O. (2016) Rusyanın Başarısız Demokratikleşme Tarihi, Birey ve Toplum Dergisi, C:6, S:8: 5-27.

Cheloukhine, S. (2017) Policing in Russia: Combatting Corruption Since the 2009 Police Reform, Springer, Cham.

Customs (2018) таможенной службы России, http://www.customs.ru/index.php (17.9.2018).

Дахин, Андрей Васильевич (2018) Правовая Норма, Идейная Позичия Государства И Мировоззренческий Выбор В Современном Сочииальном Контексте, Юридическая Наука И Практика: Вестник Нижегородской Академии Мвд России, С:1/41: 286-288.

Erdem, K. (2017) Yarı-Başkanlık ya da Süper Başkanlı: Rusya Federasyonu, Karşılaştırmalı Hükümet Sistemleri: Yarı-Başkanlık Sistemi (Fransa, Polonya ve Rusya Örnekleri) (Ed: S. Gökçimen),TBMM, Ankara: 185-243.

FSO (2018) Об Истории Создания Органов Государственной Охраны В России, Федеральная служба охраны России, http://www.fso.gov.ru/histori/ p1.html (20.9.2018).

GKS (2018) Federalnaya Slujba Gosudastvennoi Statistiki, http://www.gks.ru/ (1.9.2018).

Гонюхов С.О. vе Горобцов В.И. (2002) МВД России. 200 летнастражезакона и правопорядка. http://regiment.ru/index.htm, (10.9.2018)

MacCarthy, L. A. (2014) The Day Work of the Russian Police, Russian Analitic Digest, C: 151:5-7)

Макарова М. Н. (2011) Особенности Восприятия Органов Мвд В Общественном Мнении Региона, Мониторинг общественного мнения, C:1/101:64-70. https://cyberleninka.ru/article/v/osobennosti-vospriyatiyaorganov-mvd-v-obschestvennom-mnenii-regiona (19.9.2018)

MCHS (2018) MЧC России, http://www.mchs.gov.ru/ministry/tasks_ functions/tasks (16.9.2018)

MIL (2018) Миноборонь России, https://structure.mil.ru/structure/ministry_of_ defence/details.htm?id=11260@egOrganization (15.9.2018). 
Minjust (2018) Федеральная Служба Исполнения Наказаний, http://minjust.ru/structure/fedserv/fsin/regulation (20.9.2018)

Minjust (2019) История Министерства, https://minjust.ru/ru/history

MVD (2018) Управление «К» МВД России, https://xn--b1aew.xn-p1ai/mvd/structure1/Upravlenija/Upravlenie_K_MVD_Rossii (20.9.2018)

MVD (2018a) Общественноемнение, https://xn--b1aew.xn--p1ai/publicopinion, (20.9.2018).

MVD (2019) Структура МВД России (схема), https://xn--b1aew.xn-$\mathrm{p} 1 \mathrm{ai} / \mathrm{mvd} / \mathrm{structure} 1$ (4.7.2019)

PS (2018) Главнаястраница, Пограничнаяслужба, http://ps.fsb.ru/general.htm, (17.9.2018)

Rosgvard (2018) Rosgvardiya, http://rosgvard.ru/ru/page/index/okruga-vojsknacionalnoj-gvardii (20.9.2018)

Semukhina, Olga B. ve Reynolds, K. Michael (2012) Understanding the Modern Russian Police, CRC Press, New York.

Semukhina, Olga (2014) From Militia to Police: The Path of Russian Law Enforcement Reforms, Russian Analytical Digest, C:151:2-5).

Tataroğlu, Muhittin (2019), Karşılaştırmalı İç Güvenlik Yönetimine Giriş: Ülke Örnekleri, (ed.) T. Avaner, C. U. Çiner, Gazi Kitabevi, Eylül 2019, 163-225.

Taylor, B. D. (2018) Law Enforcement and Civil Society in Russia, Syracuse University, http://citeseerx.ist.psu.edu/viewdoc/download?doi=10.1.1.508. 4618\&rep=rep1\&type $=$ pdf (22.9.2018).

Зайцева Т.В. (2016) Материальноести мулирование государственных служащих в условиях ограниченного бюджетного финансирования, Вопросы государственного и муниципального управления, С:4: 179-197.

Zakon (1995) Федеральный Закон О Федеральной Службе Безопасности, http://www.fsb.ru/fsb/npd/more.htm\%21id\%3D10340801 \%40fsbNpa.html (22.9.2018).

Zakon, 2011) Федеральный закон "О полищии" http://www.consultant. ru/document/cons_doc_LAW_110165/(21.9.2018)

Zakonoproekt (2010) Обсуждение проекта федерального закона «О полиции», https://web.archive.org/web/20101113053653/http://www.zakonoproekt2010.r $\mathrm{u} /(21.9 .2018)$ 